\title{
Impact of Rhizosphere's Thermal Change on the Development and Production of Hydroponically Grown Cucumber under Controlled Environment
}

\author{
Muthir S. Al- Rawahy ${ }^{1 *}$, Salem A. Al- Rawahy ${ }^{2}$, Yaseen A. Al-Mulla ${ }^{2,3}$ and Saleem K. Nadaf ${ }^{4}$ \\ ${ }^{1}$ Ministry of Agriculture \& Fisheries, Sultanate of Oman \\ ${ }^{2}$ Department of Soils, Water and Agricultural Engineering, College of Agriculture \& Marine Sciences \\ Sultan Qaboos University; Sultanate of Oman \\ ${ }^{3}$ Remote Sensing and GIS Research Center, Sultan Qaboos University \\ Sultanate of Oman \\ ${ }^{4}$ Oman Animal \& Plant Genetic Resources Center, The Research Council \\ Sultanate of Oman \\ *Corresponding author's email: marwan07 [AT] live.com
}

\begin{abstract}
The easier and more economical control of root-zone temperature (RZT) as compared to that of other environmental factors such as air temperature could be an effective solution to temperature stress for the crop plants in hydroponics. The present study was designed to investigate the effect of root-zone temperature on the growth and yield of cucumber (Cucumis sativus L.) plants in recirculating hydroponic system under greenhouse of dimension, $9 m \times 30 m$ during three cropping periods of the year in Oman viz. summer (June-August), fall (SeptemberNovember) and spring (February-May) during year 2016/2017 at Directorate General Of Agriculture and Livestock Research of the Ministry of Agriculture \& Fisheries located at Rumais Barka of Oman. The plants were grown in perlite medium at root-zone cooled temperatures of $22^{\circ} \mathrm{C}, 25^{\circ} \mathrm{C}, 28^{\circ} \mathrm{C}$ treatments besides the control i.e. root-zone uncooled temperature of $33^{\circ} \mathrm{C}$ as control treatment. The treatments were arranged in Complete Randomized Design (CRD) with four replications. The results indicated that the crop at root-zone temperatures of $22^{\circ} \mathrm{C}$ and $25^{\circ} \mathrm{C}$ gave the superior performance in terms of plant height, leaf number, chlorophyll content, leaf area $\mathrm{cm}^{2}$, fruit number/m ${ }^{2}$, yield in ton per greenhouse (t/gh), fresh and dry weight of shoot and root with significant differences between the treatments in all three periods. Fruit yield varied from 4.5 t/gh to 6.4 t/gh for root-zone temperature (RZT) and from 4.2 t/gh to $6.8 \mathrm{t} / \mathrm{gh}$ for the cropping periods. The higher yields of $6.4 \mathrm{t} / \mathrm{gh}$ and $6.4 \mathrm{t} / \mathrm{gh}$ were found under RZT of $22^{\circ} \mathrm{C}$ and $25^{\circ} \mathrm{C}$, respectively and were significantly higher $(p<0.05)$ than that under control $\left(33^{\circ} \mathrm{C} ; 4.5 \mathrm{t} / \mathrm{gh}\right)$. In respect of cropping periods, the crop during fall period (February-May) gave higher fruit yield (6.8t/gh) than that during summer period (4.2t/gh). Thus the results indicated that cooling of root-zone temperature through nutrient solution is essential during high temperatures of summer (June-August) in Oman.
\end{abstract}

Keywords--- Root-zone, temperature, growth, yield, hydroponics, cucumber

\section{INTRODUCTION}

Hydroponics and soilless systems has been widely used for greenhouse cultivation of vegetable crops like cucumber, tomato, sweet pepper etc. across the world including Arabian Peninsula countries under the conditions of water stress [12]. Growth and development of the crop plants under hydroponics are influenced by various environmental factors like light and temperature. The air temperature is one of the most important environmental factors for the alternation of plant secondary metabolite production [3-5]. The temperature at the root-zone also influences the growth and chemical composition of many plants [6-10]. One of the characteristics of hydroponic cultivation is the ability to control the temperature of the nutrient solution using heaters or cooling spiral, to increase or decrease the temperature, respectively. Relatively small changes in temperature of the root environment can cause significant impact on the root development depending on phenological stage and duration of temperature [11]. Thus, the control of temperature of the nutrient solution could be a viable alternative in relation to the control of the entire protected environment. In a study with cucumber, it was reported that a combination of $15^{\circ} \mathrm{C}$ root temperature and $15^{\circ} \mathrm{C}$ air temperature prohibited growth while $30^{\circ} \mathrm{C}$ root temperature gave a slight increase in growth for cucumber plant maintained at $15^{\circ} \mathrm{C}$ air temperature [12]. However, maximum shoot growth was obtained at $30^{\circ} \mathrm{C}$ air temperature and $25^{\circ} \mathrm{C}$ root temperature. The root zone temperature has been shown to influence water and minerals uptake in plants [13-14]. During the midday period in the hot summers in most of the arid countries like Oman, the root-zone temperature of hydroponic systems often exceeds 
$30^{\circ} \mathrm{C}$, which strongly suppresses the physiological process of plant growth and reduces production. In view of the above, this study was designed to investigate the effect of root-zone temperature on the growth and yield of cucumber.

\section{MATERIALS AND METHODS}

\section{Study area}

The experiments were conducted in a cooled greenhouse of dimension $30 \mathrm{~m}$ long x $9 \mathrm{~m}$ wide at the Directorate General of Agriculture and Livestock Research in Rumais, Barka around $40 \mathrm{~km}$ north of capital Muscat during three periods of growing cucumber under hydroponics viz. spring (February-May), summer (June-August) and fall (SeptemberNovember) during 2016/ 2017.

\section{Microclimate monitoring}

Three air temperature and relative humidity sensors (Vaisala HMP60, Campbell scientific, USA) were fixed inside the greenhouse at $10 \mathrm{~m}$ from the cooling pad and at $10 \mathrm{~m}$ from the opposite door side and in the middle of the greenhouse. Inside solar radiation was monitored by pyranometer (CMP3-L14-PT, Campbell scientific, USA) and was installed under the cover in the middle of the greenhouse. A data logger (CR1000, Campbell scientific, USA) was used to store all air temperature, relative humidity and solar radiation sensors data.

\section{Experiment layout}

Sixteen growing channels were installed inside the greenhouse. The size of each channel was $5.3 \mathrm{~m}$ long x $0.4 \mathrm{~m}$ wide. The growing channels made of cement blocks of size $10 \mathrm{~cm}$ wide and $20 \mathrm{~cm}$ long that represented treatments were spaced $1.2 \mathrm{~m}$ apart. The treatments included three root-zone temperatures of cooling nutrient solution viz. RZT1 $\left(22 \pm{ }^{\circ} \mathrm{C}\right), \mathrm{RZT} 2$ $\left(25 \pm{ }^{\circ} \mathrm{C}\right)$ and RZT3 $\left(28 \pm{ }^{\circ} \mathrm{C}\right)$ besides the control-uncooled nutrient solution (RZT4) that had root-zone ambient temperature of over $30 \pm{ }^{\circ} \mathrm{C}$. The experiment was arranged in Randomized Complete Design (RCD) with four replications. Number of plants in each treatment was $40(20 \mathrm{x} 2)$ making total number of 640 plants in the experiment. White plastic mulch (100 micron) was used as insulation between the concrete and polyfoam pots to let drainage water from pots to return smoothly to the feeding tanks. Eight independent feeding tanks (400 liters) equipped with submersible pump (0.5HP Lawara, Italy) were fitted for each treatment. Cooled chiller coils made of cupper $1 / 2$ inch were fixed in each of the six of the eight feeding tanks (the remaining two tanks were for control) equipped with digital temperature sensors (GS3, Decagon Inc., USA) to control and adjust the temperature of the nutrient solution in the feeding tanks. Thirty two GS3 temperature sensors were arranged in such a manner that two GS3 temperature sensors were inserted in two pots at $15 \mathrm{~cm}$ depth in each treatment with code numbers from 1 to 32 in four replications and connected to the CR1000 data logger which was set at every thirty minute to record temperature of root zone of the cucumber plants in each treatment.

\section{Irrigation and fertilization}

Eight Intelligent hydroponic dosers consist of an LCD monitoring screen and three triple pumps (Autogrow system, New Zealand) were installed to monitor conductivity (EC) and $\mathrm{pH}$ of the nutrient solutions automatically by which the plants were fertigated. Seeds of cucumber variety namely; Reema F1 (Trust Seeds ) were seeded in 72 hole trays on 11/5/2016, 29/8/2016 and 8/2/2017 and transplanted in polyfoam pots in greenhouse on 24/5/2016, 8/9/2016 and 26/2/2017 soon after third true leaf appeared. Drip irrigation lines with emitter 4 liter/hour fixed in each pot was used to irrigate the plants. Time for irrigation was set at one minute for every five minute starting from 7 am morning up to 6 pm evening during the course of the experiment. Two stock solutions: SS1 containing 3kg Calcium nitrate with iron chelate $50 \mathrm{~g}$ diluted in 10 liters of water, SS2 containing $3 \mathrm{~kg}$ NPK (12:12:36+TE) with magnesium sulfate $1.5 \mathrm{~kg}$ diluted in 10 liter of water and SS3 containing 1 liter Nitric acid diluted in 20 liter of water were prepared for each treatment to feed the plants through eight Intelligent hydroponic dosers. At the beginning EC (Electro conductivity) was settled at $2 \mathrm{dSm}^{-1}$ and further increased gradually as the plant growth increased up to $2.5 \mathrm{dSm}^{-1}$ at the end of the plant cycle while pH was kept at 5.8 to 6.0 from seedling stage terminal of the crop cycle.

\section{Observation recorded}

The observed data that were recorded throughout the experiments were; Plant height $(\mathrm{cm})$, leaf number/plant, leaf area index $\left(\mathrm{cm}^{2}\right)$, chlorophyll (SPAD values), fruit number $/ \mathrm{m}^{2}$, yield $(\mathrm{kg} / \mathrm{plot})(\mathrm{t} / \mathrm{gh})$, shoot fresh weight $(\mathrm{g})$, root fresh weight $(\mathrm{g})$, shoot dry weight $(\mathrm{g})$, root dry weight $(\mathrm{g})$, shoot dry weight $(\%)$, root dry weight $(\%)$, fruit length $(\mathrm{cm})$, fruit diameter $(\mathrm{cm})$ and total soluble solids (TSS) percentage (\%) were determined.

\section{Statistical analysis}

Analysis of variance (ANOVA) and multiple comparisons (least significant difference (LSD) were performed using GenStat $12^{\text {th }}$ edition [15]. 


\section{RESULTS AND DISCUSSION}

The results presented in Tables 1 to 3 indicated the effects of two statistical parameters viz, period, temperature and their interaction were found to be significant $(\mathrm{p}<0.05)$ in respect of plant height, leaf area, fruit number and shoot dry weight whereas effects of the two variables were only significant $(\mathrm{p}<0.05)$ for the characters namely leaf number, chlorophyll content, fruit yield and shoot dry weight. However, the effect of only period was found to be significant $(p<0.05)$ in respect to both shoot and root dry matter $\%$, fruit length and fruit diameter whereas the effects of period and interaction were significant $(\mathrm{p}<0.05)$ for only TSS\%. Mean air temperature during crop cycle ranged from $25^{\circ} \mathrm{C}$ to $32^{\circ} \mathrm{C}, 29^{\circ} \mathrm{C}$ to $34^{\circ} \mathrm{C}$ and $25^{\circ} \mathrm{C}$ to $30^{\circ} \mathrm{C}$ during Feb-May, June-August and September- November of 2016/2017, respectively.

\section{Growth and yield traits}

In respect to plant height, the cucumber plants responded significantly $(\mathrm{p}<0.05)$ higher with plant height of $297.4 \mathrm{~cm}$ during June-August (summer) cropping period as compared to that during Feb-May $(217.2 \mathrm{~cm})$ and Sept-November $(217.2 \mathrm{~cm})$ (Table 1a). Similarly, the cucumber plants responded positively to cooled root-zone temperatures in comparison to uncooled root-zone temperature (control). The plants had insignificantly ( $\mathrm{p}>0.05)$ highest height at RZT$25^{\circ} \mathrm{C}(255.1 \mathrm{~cm})$ followed that at $22^{\circ} \mathrm{C}(254.6 \mathrm{~cm})$ and $28^{\circ} \mathrm{C}(252.4 \mathrm{~cm})$. In respect to interaction, plant height was significantly $(\mathrm{p}<0.05)$ highest at RZT $-28^{\circ} \mathrm{C}$ during June-August cropping period to that at RZT $-22^{\circ} \mathrm{C}$ during the same period $(314.8 \mathrm{~cm})$ (Table1a). Such effect of interaction between root temperature and period is attributed to different stages of growth of the plants as found in the studies of Moon et al. [16] from the results of which it was observed that during summer the growth rate of the stem at both temperatures had been linear for a long time already whereas in winter it was still exponential while in autumn and spring the growth rate at $25{ }^{\circ} \mathrm{C}$ was linear. The authors showed that rootzone cooling did not affect the plant height, number of nodes, and stem weight. Contrarily, it was found that root-zone heating at $33^{\circ} \mathrm{C}$ reduced leaf number, shoot length of carrots plants [10]. It was demonstrated that plants of tomato grown at the lowest and the highest root temperatures were fully normal in appearance although their size was smaller than at the optimal temperatures of 20 and $25^{\circ} \mathrm{C}$ [17] (Table 1).

In respect to leaf number, the cropping periods of February-May and September-November gave significantly more number of leaves/plant (54) than that during June-August (51) (Table 1a ). It was reported that the seasonal effect on leaf number of tomato is much smaller as compared to that on plant height. In their study, at a root temperature of $25^{\circ} \mathrm{C}$ and 25 days after transplanting e.g., plant height was $42.5 \mathrm{~cm}$ in summer and $9 \mathrm{~cm}$ in winter while leaf number was only 14.0 in summer 8.3 in winter [18]. 
Table 1 (a). "Means of plant height, leaf number and leaf area under four RZT and three cropping periods along with statistical parameters in cucumber grown under hydroponics closed-system

\begin{tabular}{|c|c|c|c|c|c|c|c|c|c|c|c|c|}
\hline & \multicolumn{3}{|c|}{ Plant Height $(\mathrm{cm})$} & & \multicolumn{3}{|c|}{ Leaf Number/plant } & & \multicolumn{3}{|c|}{ Leaf Area $\left(\mathrm{cm}^{2}\right)$} & \\
\hline RZT & \multicolumn{3}{|c|}{ Cropping Period } & Mean & \multicolumn{3}{|c|}{ Cropping Period } & Mean & \multicolumn{3}{|c|}{ Cropping Period } & Mean \\
\hline & Feb-May & Jun-Aug & Sep-Nov & & Feb-May & Jun-Aug & Sep-Nov & & Feb-May & Jun-Aug & Sep-Nov & \\
\hline $22^{\circ} \mathrm{C}$ & 224.5 & 314.8 & 224.5 & 254.6 & 58 & 51 & 58 & 56 & 372.3 & 346.9 & 311.3 & 343.5 \\
\hline $25^{\circ} \mathrm{C}$ & 241.4 & 282.7 & 241.3 & 255.1 & 56 & 50 & 56 & 54 & 372.3 & 345.9 & 322.5 & 346.9 \\
\hline $28^{\circ} \mathrm{C}$ & 207.6 & 342.0 & 207.6 & 252.4 & 51 & 54 & 51 & 52 & 336.8 & 292.0 & 290.2 & 306.3 \\
\hline $33^{\circ} \mathrm{C}$ & 195.4 & 249.8 & 195.4 & 213.5 & 50 & 48 & 50 & 49 & 323.7 & 205.1 & 268.8 & 265.8 \\
\hline \multirow[t]{2}{*}{ Means } & 217.2 & 297.4 & 217.2 & & 54 & 51 & 54 & & 351.3 & 297.5 & 298.2 & \\
\hline & F-Test & $\operatorname{LSD}(5 \%)$ & & & F-Test & $\operatorname{LSD}(5 \%)$ & & & F-Test & $\operatorname{LSD}(5 \%)$ & & \\
\hline $\mathrm{CP}$ & $* *$ & 16.8 & & & $*$ & 2.8 & & & $* *$ & 19.1 & & \\
\hline Temp. & $* *$ & 19.4 & & & $* *$ & 3.2 & & & $* *$ & 22.0 & & \\
\hline Int. & $* *$ & 33.6 & & & NS & - & & & $* *$ & 38.2 & & \\
\hline $\mathrm{CV}$ & & 9. & & & & 7.4 & & & & 8.4 & & \\
\hline
\end{tabular}

*RZT-Root Zone Temperature; CP-Cropping period; Temp.-Temperature; Int.-Interaction 
Table 1(b). "Means of chlorophyll content (SPAD), fruit number and fruit yield (t/gh) under four RZT and three cropping periods along with statistical parameters in cucumber grown under hydroponics closed-system

\begin{tabular}{|c|c|c|c|c|c|c|c|c|c|c|c|c|}
\hline & \multicolumn{3}{|c|}{ Chlorophyll (SPAD) } & & \multicolumn{3}{|c|}{ Fruit Number/m2 } & & \multicolumn{3}{|c|}{ Yield (t /greenhouse*) } & \\
\hline RZT & \multicolumn{3}{|c|}{ Cropping Period } & Mean & \multicolumn{3}{|c|}{ Cropping Period } & Mean & \multicolumn{3}{|c|}{ Cropping Period } & Mean \\
\hline & Feb-May & Jun-Aug & Sep-Nov & & Feb-May & Jun-Aug & Sep-Nov & & Feb-May & Jun-Aug & Sep-Nov & \\
\hline $22^{\circ} \mathrm{C}$ & 47.1 & 45.3 & 49.7 & 47.4 & 241 & 180 & 201 & 207 & 7.7 & 5.0 & 6.4 & 6.4 \\
\hline $25^{\circ} \mathrm{C}$ & 47.4 & 48.0 & 50.4 & 48.6 & 253 & 167 & 209 & 209 & 8.0 & 4.4 & 7.0 & 6.4 \\
\hline $28^{\circ} \mathrm{C}$ & 42.9 & 43.0 & 45.1 & 43.7 & 196 & 178 & 184 & 186 & 5.8 & 4.7 & 6.0 & 5.5 \\
\hline $33^{\circ} \mathrm{C}$ & 43.9 & 44.3 & 45.4 & 44.5 & 197 & 101 & 156 & 151 & 5.6 & 2.8 & 5.0 & 4.5 \\
\hline \multirow[t]{2}{*}{ Means } & 45.3 & 45.1 & 47.6 & & 222 & 156 & 187 & & 6.8 & 4.2 & 6.1 & \\
\hline & F-Test & $\mathrm{LSD}(5 \%)$ & & & F-Test & LSD(5\%) & & & F-Test & LSD(5\%) & & \\
\hline $\mathrm{CP}$ & *** & 0.96 & & & ** & 17.2 & & & $* *$ & 0.57 & & \\
\hline Temp. & ** & 1.11 & & & *** & 19.9 & & & ** & 0.66 & & \\
\hline Int. & NS & - & & & ** & 34.5 & & & NS & - & & \\
\hline $\mathrm{CV}$ & & 2.9 & & & & 12.8 & & & & 14.0 & & \\
\hline
\end{tabular}

*RZT-Root Zone Temperature; CP-Cropping period; Temp.-Temperature; Int.-Interaction; Greenhouse Area-30m x 9m=270 m²) 
No apparent interaction between period and root temperature was observed with leaf number as was the case with plant height since leaf number increased linearly with time. In the present study, effect of RZT on number of leaf /plant was significant and highest at RZT- $22^{\circ} \mathrm{C}(56)$ followed insignificantly by that at $25^{\circ} \mathrm{C}(54)$. These RZTs, however, showed significantly higher leaf number than uncooled RZT (control) $33^{\circ} \mathrm{C}$ (49). These results were in agreement with Sakamoto and Suzuki [10] who found that root-zone heating at $33^{\circ} \mathrm{C}$ reduced leaf number and shoot length of carrots plants. Similarly, Moon et al. [16] revealed that leaves and stem height had slow growth rate as root-zone temperature increased after 7 and 14 days of planting. Further, plant height, leaf number, leaf area were all significantly reduced in the study of tomato on influence of rhizosphere temperature on growth, development and physiological metabolism of greenhouse tomato in summer [19] (Table 1a).

In respect to leaf area, February-May cropping period, which falls in severe winter during February produced significantly highest leaf area of $351.3 \mathrm{~cm}^{2}$ in comparison with other two cropping periods (Table 1a). Similarly, Denise et al. [20] indicated the superiority of the winter period in terms of leaf area index which at the end of the cycle was 3.74, being $3.0 \%$ higher than the autumn period. In Iran, it was revealed leaf area varying from $265.8 \mathrm{~cm}^{2}$ to $346.9 \mathrm{~cm}^{2}$ across root-zone temperatures (RZT) [21]. In the present study, cooled RZT of $25^{\circ} \mathrm{C}$ and $22^{\circ} \mathrm{C}$ gave high leaf area of 346.9 and $343.5 \mathrm{~cm}^{2}$ respectively as compared to uncooled RTZ (control) $33^{\circ} \mathrm{C}$ (Table 1a). Qiu-yan et al. [22] reported that strong interactions were observed between RZT and nutrients on leaf area and concluded that higher biomass and growth of cucumber seedlings were produced at RZT of $20^{\circ} \mathrm{C}$. Hye et al [23] indicated that leaves of cucumber at $35^{\circ} \mathrm{C}$ root-zone temperature (RZT) had severely smaller leaf area whereas the differences in leaf morphologies were reflected by the higher leaf areas from plants grown at root-zone temperature of $30^{\circ} \mathrm{C}$ as opposed to $15.6^{\circ} \mathrm{C}$ [24].

Color pigmentation in plants, especially chlorophyll is important for their growth and yield. Hence, leaf color, as faction of chlorophyll content could be used as indication of nutrient status in the plants. In the present study, SPAD values recorded for chlorophyll were used to indicate the effect of root-zone temperatures on cucumber plants and their interactions. The SPAD values varied from 45.1 to 47.6 and from 43.7 to 48.6 for periods and root-zone temperatures (RZT), respectively (Table $1 \mathrm{~b}$ ). Many studies revealed that high temperatures could affect physiology process such as chlorophyll content and metabolism of plant. Heat stress causes an imbalance in plant metabolism and disruption of cellular homeostasis, resulting in deleterious damage to plant cells [25]. Further, Heat stress to the roots was also also found to trigger significant alternations in plant physiological processes such as water uptake and leaf photosynthesis [25- 26]. whereas Masaru et al. [27]observed that the high root-zone temperature treatment induced plant withering within 2 months or decreased the chlorophyll content as expressed by the SPAD value. The results of present study were in agreement with previous above findings. The chlorophyll content in terms of SPAD was found to significantly higher at RZT $-25^{\circ} \mathrm{C}$ and RZT $-22^{\circ} \mathrm{C}$ to the extent of 48.6 and 47.4 , respectively compared those at RZT- $28^{\circ} \mathrm{C}$ and $33^{\circ} \mathrm{C}-\mathrm{RZT}$ with SPAD values of 43.7 and 44.5, respectively (Table 1b). This could be explained by higher content of chlorophyll which is positively associated with the nutrient uptake status of the plants and photosynthesis rate at $22^{\circ} \mathrm{C}$ and $25^{\circ} \mathrm{C}$. Masaru et al. [27] reported that the number of leaves and SPAD value tended to get increased by root-zone cooling while the SPAD values of the surviving plants from the high root-zone temperature treatment were decreased after four months. In respect of effect of cropping periods, the amount of chlorophyll content in the leaves as expressed by SPAD values were significantly $(\mathrm{p}<0.05)$ higher in September-November $(47.6)$ as compared to those in other two cropping periods (Table 1b). Youssef et al. [28] found no significant effects of interaction between periods and the root-zone temperature (RZT) in chlorophyll contents.

In respect to fruit number, cucumber plants of cooled RZT $-22^{\circ} \mathrm{C}$ and $25^{\circ} \mathrm{C}$ produced more fruit number/ $\mathrm{m}^{2}$ to the extent of 207 and 209 respectively that those at RZT $-28^{\circ} \mathrm{C}$ (186) and control (151) (Table 1b). The results of present study were in agreement with those of Moon et al.[29] who reported that the number of fruits per plant to be 15.9 in non-cooled root-zone while it was 19.3 in cooled root-zone. In respect of cropping periods, February-May produced high number of fruits $\left(222 / \mathrm{m}^{2}\right)$ followed by September-November which gave $187 / \mathrm{m}^{2}$ and the lowest was given by June-August $\left(156 / \mathrm{m}^{2)}\right.$ (Table 1b). Moon et al. [29] revealed that severe growth and development inhibition by high temperature in summer were observed in cucumber. With regard to interactions effect, Feb-May and September-November and root-zone temperature at $22^{\circ} \mathrm{C}$ and $25^{\circ} \mathrm{C}$ produced higher number of fruits $/ \mathrm{m}^{2}$ as compared to June-August (Table 1b). High temperature in greenhouse during summer inhibits crop growing especially at RZT that was accompanied with high environmental temperature [30].

It is a fact that environmental stress would affect growth, development and yield of any crop. RZT is the important factor that can effect plant growth and yield through uptake of water and nutrient [31-33]. In the present study significant $(\mathrm{p}<0.05)$ differences were obtained in fruit yield between the cropping periods and root-zone temperatures (RZT) among the treatments with no significant interactions (Table 1b). With respect to cropping periods, fruit yield ranged from $4.2 \mathrm{t} / \mathrm{gh}$ to $6.8 \mathrm{t} / \mathrm{gh}$. February-May period produced the significantly highest yield of $6.8 \mathrm{t} / \mathrm{gh}$ followed by September-November $(6.1 \mathrm{t} / \mathrm{gh})$ whereas lowest yield was obtained during June-August (4.2t/gh) (Table 1b). Low yield in summer was attributed to high air temperatures (PACA,2016) during this period of the year in Oman and other Arabian Peninsula and other arid countries. Severe growth and development inhibition by high temperature in summer have been 
recorded from cucumber by many authors, for instance, reported higher yields of cucumber during both March to June and September to November as compared those in during summer period, especially in July and August in Korea [34]. Similarly, Lee [35] and Du and Tachibana [36-37] revealed that high temperature in summer and low temperature in winter are one of the main factors in reducing productivity in the year-round cultivation of cucumber. Further, they observed that below $12-13{ }^{\circ} \mathrm{C}$ RZT, growth was suspended and over $35^{\circ} \mathrm{C}$ RZT, growth was found inhibited. With regard to RZT, fruit yield varied from $4.5 \mathrm{t} / \mathrm{gh}$ to $6.4 \mathrm{t} / \mathrm{gh}$ between the treatments. Cucumber produced higher yields of $6.4 \mathrm{t} / \mathrm{gh}$ $6.4 \mathrm{t} / \mathrm{gh}$ and $5.5 \mathrm{t} / \mathrm{gh}$, respectively, at RZT $22^{\circ} \mathrm{C}, 25^{\circ} \mathrm{C}$ and $28^{\circ} \mathrm{C}$ of the cooled root-zone as compared to uncooled root-zone temperature of control $33^{\circ} \mathrm{C}(4.5 \mathrm{t} / \mathrm{gh})$ (Table $\left.1 \mathrm{~b}\right)$. These results were in in agreement with Moon et al. [29] who found that most remarkable effect of root-zone cooling was the increase of the yield in cucumber as compared to cucumber grown in non-cooled root-zone. Similarly, Lee [35] reported that as the plants grew, the yield of cucumber fruits proportionally decreased with increased root-zone temperature. In the case of tomato also, when the root-zone temperature was cooled to $25^{\circ} \mathrm{C}$ under high air temperatures, vegetative growth was improved by increasing leaf area and plant height as compared with uncooled plants at root zone, and fruit yield was found increased [38-40]. Although interactions did not significantly affect the fruit yield of cucumber in the present study, it was numerically higher at all RZTs in all three cropping periods as compared to uncooled RZT $-33^{\circ} \mathrm{C}$ (control). These findings suggested that cooled of root-zone of cucumber through cooled nutrient solution temperature especially during summer periods result in increased yield of cucumber (Table 1b).

\section{Weight related traits on a plant basis}

In respect to effect of cropping periods, the crop grown during September- November gave significantly $(\mathrm{p}<0.05)$ more shoot fresh weight (314.5 g/plant) than that of June-August period $(237.1 \mathrm{~g} / \mathrm{plant})$ and it was insignificantly different to the crop of February-May (305.0 g/plant) (Table 2a). In respect of effect of RZT, the crop with $25^{\circ} \mathrm{C}$ gave significant highest shoot fresh weight $(365.4 \mathrm{~g} /$ plant $)$ to that of RZT- $22^{\circ} \mathrm{C}(302.4 \mathrm{~g} / \mathrm{plant})$ and the lowest was given by control $\left(\right.$ RZT $\left.-33^{\circ} \mathrm{C}\right)(242.6 \mathrm{~g} /$ plant $)$ (table 2a). Daskalaki and Burrage [41] found that shoot fresh weight was highest at $28^{\circ} \mathrm{C}$ and lowest at $12^{\circ} \mathrm{C}$. Adebooye et al. [42] found significantly $(\mathrm{P} \leq 0.05)$ higher number of tendrils, number of leaves, fresh leaf weight, stem length, fresh stem weight, root length, root weight and root volume at $30^{\circ} \mathrm{C}$ as compared to $20^{\circ} \mathrm{C}$ and $25^{\circ} \mathrm{C}$ in tomato crop. In another study with muskmelon, it was reported that plant fresh weight gain for large plants was highest at the RZT- $25^{\circ} \mathrm{C}$ whereas for small plants fresh weight gain was similar from 25 to $35^{\circ} \mathrm{C}$ [43]. Jin Sun et al. [44] reported that RZ cooling increased plant shoot fresh weight, root fresh weight, shoot dry weight, root dry weight, total plant fresh weight, and total plant dry weight by $8.9,20.5,7.8,14.3,9.7$, and $8.5 \%$, respectively in Lettuce. 
Table 2(a). "Means of shoot fresh weight (g), shoot dry weight (g) and shoot dry matter (\%) under four RZT and three cropping periods along with statistical parameters in cucumber grown under hydroponics closed-system

\begin{tabular}{|c|c|c|c|c|c|c|c|c|c|c|c|c|}
\hline & \multicolumn{3}{|c|}{ Shoot fresh weight (g) } & & \multicolumn{3}{|c|}{ Shoot dry weight (g) } & & \multicolumn{3}{|c|}{ Shoot Dry matter (\%) } & \\
\hline RZT & \multicolumn{3}{|c|}{ Cropping Period } & Mean & \multicolumn{3}{|c|}{ Cropping Period } & Mean & \multicolumn{3}{|c|}{ Cropping Period } & Mean \\
\hline & Feb-May & Jun-Aug & Sep-Nov & & Feb-May & Jun-Aug & Sep-Nov & & Feb-May & Jun-Aug & Sep-Nov & \\
\hline $22^{\circ} \mathrm{C}$ & 321.2 & 264.1 & 321.8 & 302.4 & 55.0 & 48.7 & 52.5 & 52.1 & 17.1 & 18.7 & 16.3 & 17.4 \\
\hline $25^{\circ} \mathrm{C}$ & 358.6 & 274.2 & 365.4 & 332.7 & 59.4 & 49.3 & 56.7 & 55.1 & 16.7 & 18.5 & 15.7 & 17.0 \\
\hline $28^{\circ} \mathrm{C}$ & 281.1 & 222.0 & 290.4 & 264.5 & 39.5 & 39.8 & 44.5 & 41.3 & 14.1 & 18.2 & 15.5 & 15.9 \\
\hline $33^{\circ} \mathrm{C}$ & 259.2 & 188.2 & 280.5 & 242.6 & 44.7 & 37.1 & 42.8 & 45.5 & 17.2 & 20.1 & 15.4 & 17.6 \\
\hline \multirow[t]{2}{*}{ Means } & 305.0 & 237.1 & 314.5 & & 49.6 & 43.7 & 49.1 & & 16.3 & 18.9 & 15.7 & \\
\hline & F-Test & $\mathrm{LSD}(5 \%)$ & & & F-Test & $\operatorname{LSD}(5 \%)$ & & & F-Test & $\mathrm{LSD}(5 \%)$ & & \\
\hline $\mathrm{CP}$ & ** & 12.5 & & & ** & 2.4 & & & $* *$ & 1.6 & & \\
\hline Temp. & ** & 14.4 & & & ** & 2.8 & & & NS & - & & \\
\hline Int. & NS & - & & & ** & 4.8 & & & NS & - & & \\
\hline $\mathrm{CV}$ & & 12 & & & & 7.0 & & & & 13.2 & & \\
\hline
\end{tabular}

*RZT-Root Zone Temperature; CP-Cropping period; Temp.-Temperature; Int.-Interaction 
Table 2(b). ${ }^{*}$ Means of root fresh weight (g), root dry weight and root dry matter (\%) under four RZT and three cropping periods along with statistical parameters in cucumber grown under hydroponics closed-system

\begin{tabular}{|c|c|c|c|c|c|c|c|c|c|c|c|c|}
\hline & \multicolumn{3}{|c|}{ Root fresh weight (g) } & & \multicolumn{4}{|c|}{ Root dry weight (g) } & \multicolumn{3}{|c|}{ Root dry matter (\%) } & \\
\hline RZT & \multicolumn{3}{|c|}{ Cropping Period } & Mean & \multicolumn{3}{|c|}{ Cropping Period } & Mean & \multicolumn{3}{|c|}{ Cropping Period } & Mean \\
\hline & Feb-May & Jun-Aug & Sep-Nov & & Feb-May & Jun-Aug & Sep-Nov & & Feb-May & Jun-Aug & Sep-Nov & \\
\hline $22^{\circ} \mathrm{C}$ & 45.0 & 38.0 & 41.9 & 41.6 & 21.1 & 20.2 & 21.2 & 20.8 & 47.4 & 53.7 & 51.2 & 50.8 \\
\hline $25^{\circ} \mathrm{C}$ & 45.2 & 36.0 & 39.6 & 40.3 & 20.8 & 20.0 & 21.0 & 20.6 & 46.5 & 56.2 & 53.7 & 52.2 \\
\hline $28^{\circ} \mathrm{C}$ & 38.2 & 34.8 & 34.9 & 36.0 & 18.0 & 17.6 & 18.3 & 18.3 & 48.0 & 51.5 & 53.0 & 50.9 \\
\hline $33^{\circ} \mathrm{C}$ & 34.2 & 28.9 & 31.0 & 31.4 & 17.6 & 16.6 & 17.2 & 17.2 & 51.5 & 57.8 & 55.8 & 55.1 \\
\hline Means & 40.6 & 34.4 & 36.8 & & 19.4 & 18.6 & 19.4 & & 48.4 & 54.8 & 53.5 & \\
\hline & F-Test & $\operatorname{LSD}(5 \%)$ & & & F-Test & $\operatorname{LSD}(5 \%)$ & & & F-Test & $\operatorname{LSD}(5 \%)$ & & \\
\hline $\mathrm{CP}$ & $* *$ & 3.4 & & & $* *$ & 0.56 & & & $* *$ & 4.5 & & \\
\hline Temp. & $* *$ & 3.9 & & & $* *$ & 0.65 & & & NS & - & & \\
\hline Int. & NS & - & & & NS & - & & & NS & - & & \\
\hline $\mathrm{CV}$ & & 12 & & & & 4.1 & & & & 12.1 & & \\
\hline
\end{tabular}

*RZT-Root Zone Temperature; CP-Cropping period; Temp.-Temperature; Int.-Interaction 
Shoot dry weight varied from $43.7 \mathrm{~g}$ to $49.6 \mathrm{~g}$ and from $41.3 \mathrm{~g}$ to $55.1 \mathrm{~g}$ for periods and RZTs, respectively with significant $(\mathrm{p}<0.05)$ effects. The crops of February-May period (49.6g) and September-November period $(49.1 \mathrm{~g})$ were significantly highest $(\mathrm{p}<0.05)$ to that of June-August period which was the lowest $(43.7 \mathrm{~g})$. In respect of RZT, cooled RZT- $25^{\circ} \mathrm{C}$ gave significantly the highest shoot dry weight $(55.1 \mathrm{~g})$ to the cooled RZT- $22^{\circ} \mathrm{C}(52.1 \mathrm{~g})$. However, the shoot dry weight at RZT- $28^{\circ} \mathrm{C}(41.3 \mathrm{~g})$ and $\mathrm{RZT}-33^{\circ} \mathrm{C}$ (control; $\left.45.5 \mathrm{~g}\right)$ were significantly low. The result obtained by different researchers $(9-10,45)$ also showed that RZT influences the vegetative growth and biomass of the plant. Accordingly, the results of the present study are in agreement with James. A. et al. [46] who reported that root and shoot dry weight, rate of shoot growth, plant height, and water use peaked at $25^{\circ} \mathrm{C}$, which was considered as optimal temperature. Significant $(\mathrm{p}<0.05)$ differences were revealed in interactions as the crops of the periods February-May and September-November gave the higher shoot dry weights (g) at cooled RZT at $25^{\circ} \mathrm{C}$ and $22^{\circ} \mathrm{C}$. In lettuce growth was remarkably improved by RZ Cooling and that it was feasible in cultivating hydroponic lettuce in a high-temperature period through cooling of the nutrient solution [44]. The results of the present study also demonstrated that the growth of cucumber can be promoted by cooling of root-zone temperature through cooling of nutrient solution temperature during summer (June -August) period (Table 2a).

In respect of root fresh weight, it was significantly highest ( $\mathrm{p}<0.05)$ in the crop of Feb-May $(40.6 \mathrm{~g})$ to that of both JuneAugust (34.4 g) and September- November (36.8). (Table 2b). With respect to RZT, the crops at RZTs $22^{\circ} \mathrm{C}$ and $25^{\circ} \mathrm{C}$ gave significantly highest root fresh weights of $41.6 \mathrm{~g} / \mathrm{plant}$ and $40.3 \mathrm{~g} / \mathrm{plant}$ to that of RZT $-28^{\circ} \mathrm{C}(36.0 \mathrm{~g} / \mathrm{plant})$ and RZT- $33^{\circ} \mathrm{C}(31.4 \mathrm{~g} /$ plant $)$ (Table $\left.2 \mathrm{~b}\right)$. In another study shoot fresh weight was highest at $28^{\circ} \mathrm{C}$ and lowest at $12^{\circ} \mathrm{C}[42]$. Root zone temperatures $(\mathrm{T})$ caused statistically significant $(\mathrm{p} \leq 0.05)$ positive effects on the average number of tendrils, number of leaves, fresh leaf weight, stem length, fresh stem weight, root length, fresh root weight and root volume and they were parameters were highest at $30^{\circ} \mathrm{C}$ as compared to $20^{\circ} \mathrm{C}$ and $25^{\circ} \mathrm{C}$ in tomato crop [41]. It was reported that RZ cooling increased plant shoot fresh weight, root fresh weight, shoot dry weight, root dry weight, total plant fresh weight, and total plant dry weights by $8.9,20.5,7.8,14.3,9.7$, and $8.5 \%$, in lettuce respectively [44]. Significant $(\mathrm{p}<0.05)$ effects of root-zone cooling were observed in root dry weight between the treatments (Table $2 b$ ) as those of cropping periods $(\mathrm{p}<0.05)$ in the present study. Root dry weight varied from $18.6 \mathrm{~g}$ to $19.4 \mathrm{~g}$. February-May and September-November gave the highest root dry weights (19.4g) while the lowest was found with June-August (18.6 g) (Table 2b). These results were in agreement with findings of Schmidt et al. [47] who reported that at the end of the cycle, the root dry mass accumulation of lettuce was $68.72 \mathrm{~g} / \mathrm{m}^{2}$ and $46.76 \mathrm{~g} / \mathrm{m}^{2}$ for the autumn and winter periods, respectively. The superiority of the autumn period was possibly related to the temperature of the nutrient solution and the environment inside the growing profile, which was lower during the autumn period. Jin Sun et al. (2016) showed that lettuce growth was remarkably improved by RZ Cooling. With regard to root-zone cooling effects, the crops with root-zone at temperatures $22^{\circ} \mathrm{C}$ and $25^{\circ} \mathrm{C}$ gave significantly the highest root dry weights of $20.8 \mathrm{~g}$ and $20.6 \mathrm{~g}$, respectively to RZT- $28^{\circ} \mathrm{C}(18.3 \mathrm{~g})$ and RZT- $33^{\circ} \mathrm{C}$ (control; 17.2g) (Table 2b). Similar results were obtained in earlier studies [9-10, 45] James et al. [46] reported that root and shoot dry weight, rate of shoot growth, plant height, and water use peaked at $25^{\circ} \mathrm{C}$ and that optimal temperature was found to be approximately $25^{\circ} \mathrm{C}$

The values of dry matter $\%$ were significant only for cropping periods ( $<<0.05)$. Accordingly, shoot and root dry matter percentages $(\%)$ were significantly $(\mathrm{p}<0.05)$ higher in summer period (June-August) $(18.9 \%$ \& $54.8 \%)$ than those in February-May (16.3\% and $48.4 \%)$. However, with respect to root-zone temperatures, shoot and root had the insignificantly the highest dry matter percentages at RZT $33^{\circ} \mathrm{C}$ (control) $(17.6 \%$ and $55.1 \%)$ as compared to those at RZTs of $22^{\circ} \mathrm{C}, 25^{\circ} \mathrm{C}$ and $28^{\circ} \mathrm{C}$ (Tables $2 \mathrm{a}$ and b). These results are in agreement with Masaru and Takahiro [48] who observed that despite the absence of significant differences between RZTs, the shoot and root dry matter $\%$ under low root-zone temperature treatment tended to be lower than those of the plants under ambient root-zone temperature treatment. However, Jin Sun et al. (2016) showed that root zone cooling increased plant shoot and root weights besides their dry matter $\%$.

\section{Quality attributes}

In respect to quality traits of cucumber, fruit length varied from $14.3 \mathrm{~cm}$ to $16.5 \mathrm{~cm}$ and from $15.4 \mathrm{~cm}$ to $15.5 \mathrm{~cm}$ for the cropping periods and root-zone temperature respectively with significant $(\mathrm{p}<0.05)$ differences only between the periods (Table 3). The crop of Feb-May period gave highest fruit length of $16.5 \mathrm{~cm}$ whereas the lowest was observed in the crop of September-November period $(14.3 \mathrm{~cm})$. Similarly, with regard to fruit diameter, significantly differences were observed only between the periods. The crop of September-November gave highest fruit diameter $(3.3 \mathrm{~cm})$ whereas that of June-August period was the lowest $(3.1 \mathrm{~cm})$. In general, the crops with RZT $22^{\circ} \mathrm{C}$ and $25^{\circ} \mathrm{C}$ had the higher fruit length $(15.5 \mathrm{~cm})$ and diameter $(3.3 \mathrm{~cm})$. 
Table 3. * Means of fruit length, fruit diameter and total soluble solids (TSS \% as brix) under four RZT and three cropping periods along with statistical parameters in cucumber grown under hydroponics closed-system

\begin{tabular}{|c|c|c|c|c|c|c|c|c|c|c|c|c|}
\hline & \multicolumn{3}{|c|}{ Fruit length $(\mathrm{cm})$} & & \multicolumn{4}{|c|}{ Fruit diameter $(\mathrm{cm})$} & \multicolumn{3}{|c|}{ Total soluble solids (\%) } & \\
\hline RZT & \multicolumn{3}{|c|}{ Cropping Period } & Mean & \multicolumn{3}{|c|}{ Cropping Period } & Mean & \multicolumn{3}{|c|}{ Cropping Period } & Mean \\
\hline & Feb-May & Jun-Aug & Sep-Nov & & Feb-May & Jun-Aug & Sep-Nov & & Feb-May & Jun-Aug & Sep-Nov & \\
\hline $22^{\circ} \mathrm{C}$ & 16.5 & 15.5 & 14.3 & 15.4 & 3.4 & 3.2 & 3.3 & 3.3 & 3.8 & 2.5 & 3.7 & 3.3 \\
\hline $25^{\circ} \mathrm{C}$ & 16.8 & 15.2 & 14.5 & 15.5 & 3.5 & 3.1 & 3.4 & 3.3 & 3.6 & 2.9 & 3.6 & 3.3 \\
\hline $28^{\circ} \mathrm{C}$ & 16.6 & 15.3 & 14.3 & 15.4 & 3.2 & 3.1 & 3.3 & 3.2 & 3.6 & 2.6 & 3.5 & 3.2 \\
\hline $33^{\circ} \mathrm{C}$ & 16.2 & 16.1 & 14.2 & 15.5 & 3.4 & 3.0 & 3.3 & 3.2 & 3.9 & 2.4 & 4.0 & 3.4 \\
\hline \multirow[t]{2}{*}{ Means } & 16.5 & 15.5 & 14.3 & & 3.3 & 3.1 & 3.3 & & 3.7 & 2.6 & 3.7 & \\
\hline & F-Test & $\operatorname{LSD}(5 \%)$ & & & F-Test & $\operatorname{LSD}(5 \%)$ & & & F-Test & $\operatorname{LSD}(5 \%)$ & & \\
\hline $\mathrm{CP}$ & $* *$ & 0.46 & & & $* *$ & 0.13 & & & $* *$ & 0.19 & & \\
\hline Temp. & NS & - & & & NS & - & & & NS & - & & \\
\hline Int. & NS & - & & & NS & - & & & $* *$ & 0.39 & & \\
\hline $\mathrm{CV}$ & & 4.1 & & & & 5.6 & & & & 8.1 & & \\
\hline
\end{tabular}

*RZT-Root Zone Temperature; CP-Cropping period; Temp.-Temperature; Int.-Interaction 
The results indicated significant $(\mathrm{p}<0.05)$ differences in TSS (total soluble solids percentage as brix) of cucumber fruits between periods. The TSS was also affected significantly by the interactions ( $<<0.05)$. February-May and September-November gave the highest TSS (3.7\%). The crops of September- November and February-May had the higher TSS of 4.0 and 3.9, respectively at RZT of $33^{\circ} \mathrm{C}$. Mohamed [49] indicated that TSS did not differ between the two cucumber cultivars in two growing periods studied. Similar to the present study, Peyvast et al [50] found no significant effects on RZTs in total soluble solids percentage in cucumber fruits. The results of the present study indicated that root-zone temperatures did not affect the quality of cucumber fruits, as this could be associated with other physiological factors, nutrient uptake of cucumber in different periods.

\section{CONCLUSION}

The results of the present study showed that RZTs of $22^{\circ} \mathrm{C}$ and $25^{\circ} \mathrm{C}$ were effectives in all characters tested for cucumber in all the three cropping periods studied. However, the present experiment aimed at comprehending cucumber's response for summer period in which production of cucumber would be affected by very high temperatures coupled with occurrence of Phythium disease. The findings indicated that cooling of root-zones of cucumber through cooled nutrient solution during summer periods would result in increased yield of cucumber.

\section{ACKNOWLEDGEMENTS}

The authors' expresses are grateful to the financial grants of Agriculture and Fisheries Development Fund (AFSF) of the Ministry of Agriculture \& Fisheries for the research project leading to Ph.D. degree of the main author who also thank the Director General of Agriculture \& Livestock Research, Director of Plant Production Research Center and Director of Soil and Water Research Center for their supports in logistics and facilities to conduct several experiments. Thanks are also to the advisor, members of the advisory committee and all the concerned staff of the College of Agriculture \& Marine Sciences and Directorate General of Agriculture \& Livestock Research (DGALR) who have directly and indirectly assisted in conducting the experiments of the research project.

\section{REFERENCES}

[1]. Jensen and Malter, "Protected Agriculture; A Global Review", Vol, 23- 253, 1995.

[2]. M.D. Sardare , S.V. Admane, "A Review on Plant without Soil- Hydroponics", International Journal of Research in Engineering and Technology, Vol,2 issue,3, 2013.

[3] Kaplan F, Kopka J, Haskell DW, Zhao W, Schiller KC, Gatzke N, Guy CL, "Exploring the temperature-stress metabolome of arabidopsis", Plant Physiology, vol. 136, 4159-4168, 2004.

[4] Zobayed S M A, Afreen F, Kozai T, "Temperature stress can alter the photosynthetic efficiency and secondary metabolite concentrations in St. John's Wort", Plant Physiology and Biochemistry, vol. 43, 977-984, 2013. http://dx.doi.org/10.1016/j.plaphy.2005.07.013

[5] Ramakrishna A, Ravishankar GA "Influence of abiotic stress signals on secondary metabolites in plants", Plant Signaling \& Behavior, vo. 6, 1720-1731, 2011. http://dx.doi.org/10.4161/psb.6.11.17613

[6]. Adebooye, O. C., Schmitz-Eiberger, M., Lankes, C., Noga, G. J. Inhibitory effects of sub-optimal rootzone temperature on leaf bioactive components, photosystem II (PS II) and minerals uptake in Trichosanthes cucumerina L. Cucurbitaceae. Acta Physiologiae Plantarum, 32, 67-73, 2010.

[7]. Malik, S., Andrade, S. A. L., Sawaya, A. C. H. F., Bottcher, A.,Mazzafera, P. Root-zone temperaturealters alkaloid synthesis and accumulation in Catharanthus roseus and Nicotiana tabacum. Industrial Crops and Products, 49, 318-325, 2013. http://dx.doi.org/10.1016/j.indcrop.2013.05.009

[8]. Qiu. Yan., Zeng. Giang and Jing. Dong Mao, Low Root Zone Temperature Limits Nutrient Effects on Cucumber Seedling Growth and Induces Adversity Physiological Response. Volume 12, Issue 8, Pages 1450-1460. 2013. https://doi.org/10.1016/S2095-3119(13)60549-3

[9]. Sakamoto, M., Suzuki, T, Elevated root-zone temperature modulates growth and quality of hydroponically grown carrots. Agricultural Sciences, 6, 749-757 2015a. http://dx.doi.org/10.4236/as.2015.68072.

[10]. Sakamoto, M., Suzuki, T, Effect of root-zone temperature on growth and quality of hydroponically grown red leaf lettuce (Lactuca sativa L. cv. Red Wave). American Journal of Plant Sciences, 6, 2350-2360 2015b. http://dx.doi.org/10.4236/ajps.2015.614238.

[11]. Rodrigues Lrf, Cultivo pela técnica de hidroponia: técnicas de cultivo hidropônico e de controle ambiental no manejo de pragas, doenças e nutrição vegetal em ambiente protegido. Jaboticabal: FUNEP, 726p. Root Zone Cooling and Exogenous Spermidine Root-Pretreatment Promoting Lactuca sativa L. Growth and Photosynthesis in the Hightemperature Season Chiba University, Chiba, Japan ,2002.

[12]. Karlsen P, The influence of root and air temperature on young cucumber plants. Acta Horticulturae 118: 95-104, 1981.

[13]. Diczbalis Y, Menzel C.M., Low temperatures decrease CO2 assimilation and growth in the tropical rambutan., J. Hort. Sci. Biotechnol. 73: 65-71, 1998.

[14]. George H.L., Davies F.S., Crane J.H, Schaffer B, Root temperature effects on 'Arkin` Carambola. I. Leaf gas exchange and water relations. Scientia Horticulturae 96: 53-65, 2002.

[15]. Payne, R.W., Murray, D.A., Harding, S.A., Baird, D.B, Soutar, D.M, GenStat for Windows (12th Edition). Introduction. VSN International, Hemel Hempstead, 2009. Peyne et al., 2009. 
[16]. J.H. Moon, Y.K. Kang, H.D. Suh, Effect of Root-zone cooling on the growth and yield of cucumber at Supraoptimal Air temperature, Acta. Hort.261, ISHS, 2007.

[17]. H.Veenman, Zonen .BV., Root temperature and growth of young Tomato plants. Department of Horticulture, Agricultural University, Wageningen, The Netherlands Publication No. 443, 1977.

[18]. Li, L, The influence of different temperature on the rhizosphere to growth of tomato. M.Sc. Dissertation (Shanxi Agricultural University), 2011.

[19]. Li, L, The influence of different temperature on the rhizosphere to growth of tomato. M.Sc. Dissertation (Shanxi Agricultural University), 2011.

[20]. Denise et al. ( 2017)

[21]. Ghehsareh AM, Hematian M, Kalbasi M, Comparison of datepalm wastes and perlite as culture substrates on growing indices in greenhouse cucumber. Int. J. Recycling of Organic Waste in Agriculture 2012, 1:5 doi:10.1186/2251-7715-1-5, 2012.

[22]. Qiu. Yan., Zeng. Giang, Jing. Dong Mao, Low Root Zone Temperature Limits Nutrient Effects on Cucumber Seedling Growth and Induces Adversity Physiological Response. Volume 12, Issue 8, Pages 1450-1460, 2013. https://doi.org/10.1016/S2095-3119(13)60549-3

[23]. Hye. Moon, Hee-Ock Boo, In-Ok Jang, Effect of Root-Zone Temperature on water relation and hormone content in Cucumber. Hort. Environ. Biotechnology. 48(5):1-8, 2007.

[24]. Josh Hurewitz, Harry W. Janes, Effect of Altering the Root-Zone Temperature on Growth, Translocation, Carbon Exchange Rate, and Leaf Starch Accumulation in the Tomato. Plant Physiol. 73, 46-50, 1983.

[25]. Suzuki, N., Mittler, R, Reactive oxygen species and temperature stresses: A delicate balance between signaling and destruction. Physiologia Plantarum, 126, 45-51, 2005.

[26]. He, J., Qin, L., Lee, S. K. (2013). Root-zone CO2 and root-zone temperature effects on photosynthesis and nitrogen metabolism of aeroponically grown lettuce (Lactuca sativa L.) in the tropics. Photosynthetica, 51, 330-340. http://dx.doi.org/10.1007/s11099-013-0030-5

[27]. Masaru Sakamoto, Mayuka Uenishi, Kengo Miyamoto. Takahiro Suzuki., Effect of Root-Zone Temperature on the Growth and Fruit Quality of Hydroponically Grown Strawberry Plants. Journal of Agricultural Science; Vol. 8, No. 5; ISSN 1916-9752 E-ISSN 1916-9760 Published by Canadian Center of Science and Education, 2016.

[28]. Youssef, Nashwa ,A.I. Abu El-Azm, S.A. AbdElhady, Frequent Foliar Sprayings of Salicylic Acid with Elevated Concentrations Enhance Growth, Yield and Fruit Quality of Strawberry (Fragaria x ananassa Duch. cv. Festival) Plants Egypt. J. Hort. Vol. 44, No.1, pp.61 - 74, 2017.

[29]. J.H. Moon, Y.K Kang, H.D. Suh, Effect of Root-Zone Cooling on the Growth and Yield of Cucumber at Supra optimal Air Temperature, Proc. XXVII IHC-S6 High-Qual. Crop Prod. under Protect. Cultiv. Ed.-in-Chief: D.J. Cantliffe Acta Hort. 761,2007.

[30]. Song, M., Influence of rhizosphere temperature on growth, development and physiological metabolism of greenhouse tomato in summer. Ph.D. Dissertation (Shanxi Agricultural University), 2013.

[31]. Bode Stoltzfus RM, Taber HG, Aiello AS, Effect of increasing root-zone temperature on growth and nutrient uptake by 'Gold Star' muskmelon. J. Plant Nutr., 21, 321-328, 1998.

[32]. Lahti M, Aphalo PJ, Fine'r L, Ryyppo“ A, Lehto T, Mannerkoski H, Effects of soil temperature on shoot and root growth and nutrient uptake of 5-year old Norway spruce seedlings. Tree Physiol., 25, 115-122, 2005.

[33]. Diaz-Perez JC, Gitaitis R, Mandal B, Effects of plastic mulches on root zone temperature and on the manifestation of tomato spotted wilt symptoms and yield of tomato. Sci. Hortic., 114, 90-95, 2007.

[34]. Lee, J.W., Lee, E.H., Kwon, J.S., Kwon, Y.S., Huh, N.Y, The study about establishment of horticulture productivity improvement in institution of horticultural product. Report of Korean Horticultural Research Institute, P, 708-717, 1996.

[35]. Lee, W.S, Vegetables of Korea. 1st ed. Kyungbook Natl. Univ. Press, Taegu, Kyungpook, 1994.

[36]. Du, Y.C.,S. Tachibana, Effect of supraoptimal root temperature on the growth, root respiration and sugar content of cucumber plants. Scientia Hort. 58:289-301, 1994,a.

[37]. Du, Y.C., S. Tachibana, Photosynthesis, photosynthate translocation and metabolism in cucumber roots held at supraoptimal temperature. J. Japan. Soc. Hort. Sci. 63:401-408, 1994,b

[38]. Sasaki, K, T. Itagi, Effect of root cooling treatment of nutrient solution on growth and yield of tomato, cucumber and melon. Environ. Control Biol. 27: 89-95, 1989. (In Japanese with English abstract).

[39]. Fujishige, N., T. Sugiyama, R. Ogata., Effect of root temperature on the flower formation and fruit yield of tomatoes. J. Japan. Soc. Hort. Sci. 60: 97-103, 1991. (In Japanese with English summary).

[40]. Nkansah, G. O, T. Ito, Comparative studies on growth and development of heat-tolerant and non heat-torelant tomato plants grown at different root-zone temperatures. J. Japan. Soc. Hort. Sci. 62: 775-780, 1994.

[41]. Daskalaki A, Burrage SW, Solution temperarure and the uptake of water and nutrients by cucumber (Cucumis sativus L.). Acta Hort. 458:317-322, 1998.

[42]. Adebooye O.C., G. J. Noga, C. Lankes, Root Zone Temperature Affects Emergence And Growth Traits Of Snake Tomato (Trichosanthes Cucumerina L.), 2009. 
[43]. Rhonda M. Bode Stoltzfus, Henry G. Taber, Anthony S. Aiello (2008) Effect of increasing root-zone temperature on growth and nutrient uptake by 'gold star' muskmelon plants, Journal of Plant Nutrition,21:2, 321-328, 2008. DOI: $10.1080 / 01904169809365406$

[44]. Jin Sun, Na Lu†, Hongjia Xu, Toru Maruo, Shirong Guo, Root Zone Cooling and Exogenous Spermidine Root-Pretreatment Promoting Lactuca sativa L. Growth and Photosynthesis in the High-temperature Season Chiba University, Chiba, Japan, 2016.

[45]. Chadirin, Y., Hidaka, K., Takahashi, T., Sago, Y., Wajima, T., Kitano, M., Application of temperature stress to roots of spinach: I. Effect of the low temperature stress on quality. Environment Control in Biology, 49, 133-139, 2011. http://dx.doi.org/10.2525/ecb.49.133

[46]. James A. Tindall, H.A. Mills, D.E. Radcliffe, The effect of root zone temperature on nutrient uptake of tomato, Journal of Plant Nutrition, 13:8, 939-956, 2008. DOI: 10.1080/01904169009364127.

[47]. Schmidt, D; Gabriel, Vj; Caron, Bo; Souza, Vq; Boscaini, R; Pinheiro, Rr; Cocco, C., Hydroponic rocket salad growth and production according to different color profiles. Horticultura Brasileira 35: 111-118, 2017. DOI http://dx.doi.org/10.1590/S0102-053620170117

[48]. M. Sakamoto, T. Suzuki., Elevated root-zone temperature modulates growth and quality of hydroponically grown Carrots, Agriculture Sciences, 6, 745-757, 2015. www.scirp.org/journal/as

[49]. Mohamed Ewis Abdelaziz. , Effect Of Different Microorganisms And Substrates On Yield And Fruit Quality Of Cucumber Grown In Hydroponic System In partial fulfillment of the requirements of the degree of doctor PhD Mendel University in Brno, Czech Republic, 2010.

[50]. Peyvast, G. H.; Noorizadeh, M.; Hamidghli, J.; Ramezani-Kharazi, P, Effectsof four different substrates on growth, yield and some fruit quality parameters of cucumber in bag culture. Acta Hort. 779: 535-540, 2008. 